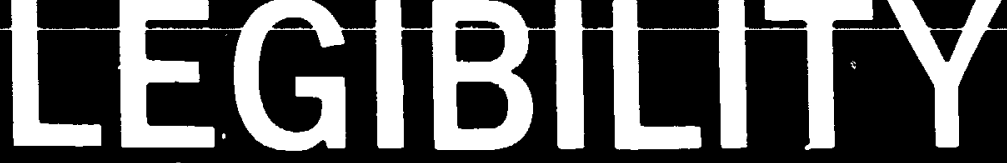

A major purpose of the Technical Information Center is to provide the broadest dissemination possible of information contained in DOE's Research and Development Reports to business, industry, the academic community, and federal, state and local governments.

Although a small portion of this report is not reproducible, it is being made available to expedite the availability of information on the research discussed herein. 
$D R-0421-9$

\title{
ENGINEERING ANALYSIS OF TFTR DISRUPTION
}

\author{
J.G. MURRAY \\ K.E. ROTHE \\ G. BRONNER
}

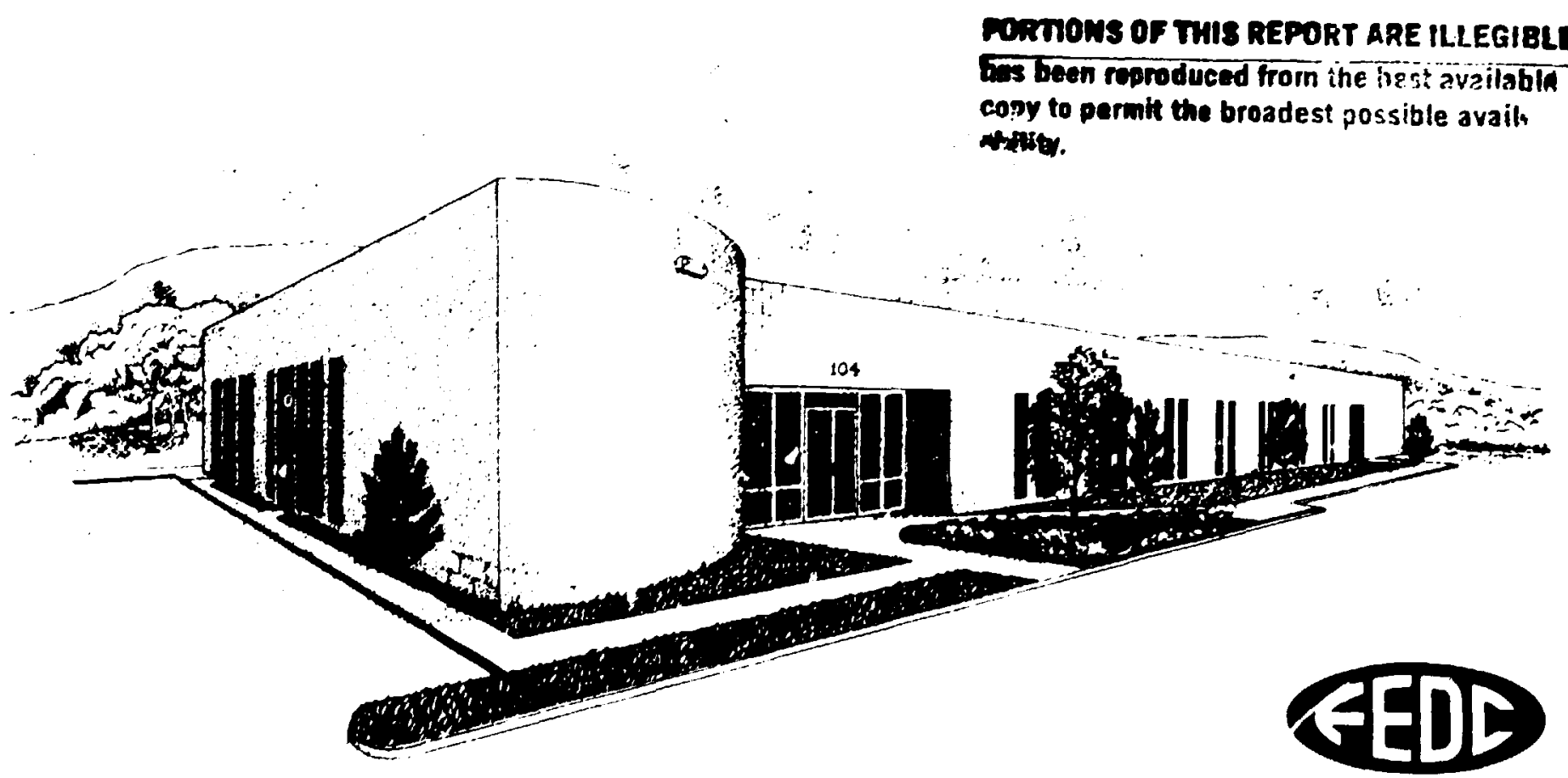

FUSION ENGINEERING DESIGN CENTER

Oak Ridge National Laboratory * Oak Ridge, Tennessee 


\title{
DISCLAIMER
}

This report was prepared as an account of work sponsored b; an ugency of the United States Governi.tent. Neither the United States Governmernt nor any agency thereof, nor any of their employees, makes any warranty, express or implied, or assumes any legal liabili:y or responsibility for the acuracy. compieteness, or usefulness of any information, apparatus, produc. or process disclosed, or represents that its use would nor infringe privately owned rights. P.ference herein to any specific commercial product. process. or service by trade name, trademark. manufacturer. or other wise does not necessarily constitute or imply its endorsement. recommendatior. or favoring ty the United States Government or any agency thereof. The views and upinions of authors expressed he:ein do noi necessurily state or reflect those of the United States Government of any agency thereof.

\author{
Fusion Energy Division
}

\section{ENGINEERING ANALYSIS OF TFTR DISRUPTION}

\author{
John G. Murray \\ Kristin E. Rothe ${ }^{\dagger}$ \\ George Bronner*
}

Dat: Published - September 1984

-Princeton Plasma Physics Laboratory.

${ }^{\dagger}$ ORNL Fusiun Engineering Design Center.

Prepared by the

OAK RIDGE NATIONAL LABORATORY

Oak Ridge, Tennessee 37831 operated by

MARTIN MARIETTA ENERGY SYSTEMS, INC.

for the

U.S. DEPARTMENT OF ENERGY

under Contract No. DE-AC05-84OR21400 


\section{CONTENTS}

Page

LIST OF FIGURES

$\mathbf{v}$

LIST OF TABLES

vii

ABSTRACT

1

1. PURPOSE AND CAPABILITY OF ENGINEERING ANALYSIS ...... 3

2. DESCRIPTION OF MODEL AND PROCEDURE $\ldots \ldots \ldots \ldots \ldots \ldots, 4$

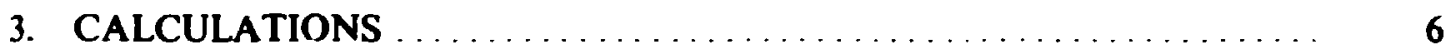

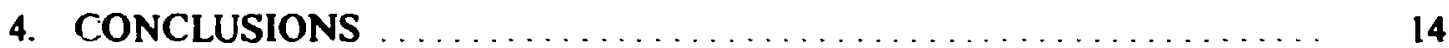

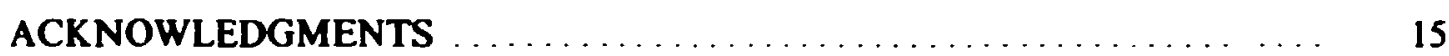

REFERENCES .... . . . 15 


\section{LIST OF FIGURES}

Figure

Page

1 Plasma temperature during current decay . . . . . . . . . . . . 6

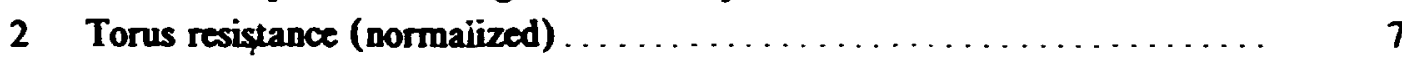

3 Torus outer wall resistance (normalized) $\ldots \ldots \ldots \ldots \ldots \ldots \ldots \ldots \ldots$

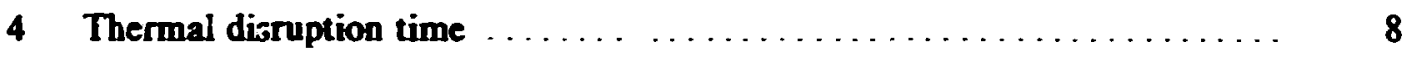

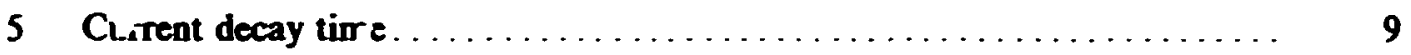

6 Plasma heat (a), radial position (b), and current (c) at $2.5 \mathrm{MA}$

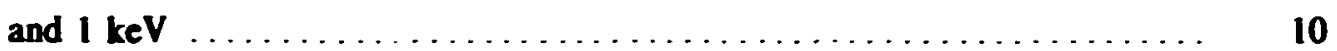

7 Plasma heat (a), radial position (b), and current (c) at 2.5 MA and $10 \mathrm{keV}$

8 Plasma heat (a), radial position (b), and current (c) at 1.0 MA and $1 \mathrm{keV}$ 


\section{LIST OF TABLES}

Table

Page

1 Volume (in $\mathrm{cm}^{3}$ ) of material vaporized or melted by initial thermal energy

2 Volume (in $\mathrm{cm}^{3}$ ) of material vaporized or melted by thermal energy added to piasma initial thermal energy by disruption

for a 1-keV plasma 


\section{ABSTRACT}

Disruption protec:inn on a reactor-relevant tokamak is a major design problem. It is a configuration as well as a maintenance design driver. Our capability to specify the characteristics of a disruption (which determines the time and magnitude of the induced currents, forces, voltages, and arc erosion) is not sufficient to warrant the risk associated with the construction of a large tokamak fusion device that has a high-condustivity shell." It is recommended that the next large device inciude a low-conductivity shell close fitting around the plasma.

Thi: report covers an engineering approach quantifying: the currents, forces, and times, as well as plasma position, for the worst-case disruption based on engineering circuit assumptions for the plasma. As the plasma moves toward the wall during the currentdecay phase of disruption, the wall currents affect the rate of movement and, hence, the decay time. The calculated structure-induced currents differ considerably from those calculated using a presently available criterion, which specifies that the plasma remains stationary in the center of the torus while decaying in $10 \mathrm{~ms}$.

This report outlines the method and basis for the engineering calculation used to determine the current and forces as a function of the circuit characteristics. It provides specific calculations for the Tokamak Fusion Test Reactor (TFTR) with variations in parameters such as the thermal decay time, the torus resistance, and plasma temperature during the current decay.

The study reviews possible ways to reduce the disruption damage of TFTR by reducing the magnitude of the plasma external field energy that is absorbed by the plasma during the curreni decay. This absorbed external field energy adds to the plasma thermal energy and increases the melting or ablation of the limiter or wall surfaces. The present TFTR disruption conditions should not encounter a significant increase in disruption magnetic energy until the plasma current is increased above $2.0 \mathrm{MA}$. The limiter or wall energy that is absorbed from the plasma magnetic field energy is $80 \mathrm{~kJ}$ at a plasma current of 1.0 MA. This increases frem 340 to $840 \mathrm{~kJ}$ when the plasma current increases from 2.0 to $2.5 \mathrm{MA}$. In addition, about $1800 \mathrm{~kJ}$ of thermal energy must be absorbed by the limiter when the plasma temperature suddenly decreases from $10 \mathrm{keV}$.

\footnotetext{
'Y-K. M. Peng and P. Ruther.ord, FED-A, An Advanced Performance FED Based on Low Safety Factor and Current Drive, ORNL/FEDC-83 I, Oak Ridge Natl. Lab., 1983.
} 


\section{PURPOSE AND CAPABILITY OF ENGINEERING ANALYSIS}

In the early stages of the Engineering Test Facility (ETF) design. the disruption was characterized in a way that allowed the preconceptual design to proceed on divertors, limiters, and first walls. A consensus of the fusion community was utilized through the workshop procedure to characterize the disruption. It was concluded that we should assume a 10-ms decay time for the disruption and that the specified energy (thermal and inductive) would be deposited at specified locations on the surfaces of the wall and limiter. This was the best characterization that could be provided at that time and is essentially the same one that is used for todzy's design concepts. The characterization should be updated because much more data have been obtained and more is known about disruptions. This report attempts, provide the impetus for this change.

A change is needed because disruption is a major driver in the engineering designs of the first wall surfaces and their structural supports. The maintainability of the limiter is a major configuration consideration. The present characterization does not account for the very fast (approximately $50_{-\mu \mathrm{s})}$ thermal decay time, for the plasma movement during the current decay, nor for the decay time changing as a function of the structure time constant and its position with respect to the plasma (self-inductance and mutual coupling to the plasma). These factors can result in differences in induced structuie eddy currents and forces by factors larger than 5, compared to those using the standard characterization.

The Advanced Performance Fusion Engineering Device (FED-A) design was based on a thick (3-cm) conducting shell closely fitted to the plasma. This configuration offers the greatest deterrent to disruptions and disruption damage. However, the engineering designs for FED-A were based on the current decay time of $10 \mathrm{~ms}$.

To provide improved quantization for the worst-case disruption, the following engineering analysis was developed. This provedure has provided results that are in good agreement with the conditions on the Princeton Large Torus (PLT) and Impurity Study Experiment (ISX) machines.' In this report, the Tokamak Fusion Test Reactor (TFTR) configuration is analyzed. The TFTR study was completed for the following reasons:

- to qualify this method of calculation for use on future designs such as the Tokamak Fusion Core Experiment (TFCX) and the Engineering Test Reactor (ETR),

- to attempt to quantify the possible TFTR disruption damage and to consider methods to improve the ability of the TFTR to withstand disruption, and

- to provide a design tool for improving the engineering with regard to disruption damage.

The procedure developed is for the worst-case condition. It is applicable to the largest and fastest thermal disruption. It provides for the calculation of the induced voltages, induced currents, and resulant forces. It also provides a basis for determining the likelihood of an arc uccurring across bellows or gaps, as well as for calculating the arcing time and coulombs. The arc erosion can then be estimated based on the diffused-arc data obtained on industrial vacuum-switch development with parallei fields. ${ }^{2}$ (A tokamak 
poloidal arc should remain in a diffused state for at least $10 \mathrm{~ms}$ before it becomes constrictive and produces erosion.)

\section{DESCRIPTION OF MODEL AND PROCEDURE}

The TFTR coils, vacuum vessel, plasma circuit, and self-inductance and mutual inductances were determined using the ICC code. Values were obtained by simulating the plasma circuit as a hot, well-confined, full-radius ring. Then a second set of inductances was determined with the plasma simulated as a low-temperature $(100-\mathrm{eV})$, small-minorradius conductor located against the inner wall. The values of the plasma self-inductance and mutual inductances used for each iteration of the computer progran. were determined from interpolation between these two sets of values as a function of the plasma radius $\boldsymbol{R}$.

The plasma circuit was simulated as a circular conductor that could vary in major radius $\boldsymbol{R}$ and minor radius $a$ in response to the current and the fields present. The only restraint on the movement was the total system conservation of energy. The vertical field that governs its position could not change faster than the change in energy could be absorbed. It was assumed that the plasma resistivity remained constant during the current decay period. It was, however, changed from a low value (hot plasma) to a high value (cold plasma), simulating the thermal decay. The plasma resistar $x$ was then calculated as a function of its major and minor radii. As the piasma moved toward the inner wall, its minor radius was reduced in proportion to the radial movement; that is, the simulation reduced the minor radius by $1.0 \mathrm{~cm}$ when the plasma moved $1.0 \mathrm{~cm}$ toward the inner wall (scrape-off of uniform magnetic surfaces).

The conservation of magnetic and electrical energy governed the plasma movement or position. As the plasma current decreased and moved inward, its field energv reduced by $\triangle 1 / 2 L I_{p}^{2}$, but its value could not change any faster than the energy could be dissipated or transferred in the total system, which included all the circuits and structures $\left(\sum I^{2} \Omega t\right.$ and $\left.\Sigma 1 / 2 L I^{\circ}\right)$. The basic ci-cuit equation was

$$
\sum\left(\frac{1}{2} L_{i i} I_{i}^{2}+M_{i j} I_{i} I_{j}\right)=E
$$

The derivative, with respect to displacement, was set equal to zero to obtain the following:

$$
\frac{d}{d R}\left[\Sigma\left(\frac{1}{2} L_{i l} I_{i}^{2}+M_{i j} I_{i} I_{j}\right)\right]=0,
$$


recognizing that

$$
\frac{d}{d R}=\frac{d}{d R} \times \frac{d t}{d R}
$$

Then,

$$
\begin{aligned}
& \sum\left\lfloor\frac{1}{2}\left(\frac{d}{d R} L_{i j}\right) I_{i}^{2}+\left\lfloor\frac{d}{d R} M_{i j}\right) I_{i} I_{j}\right] \\
& +\sum\left\lceil\frac{1}{2} L_{i i}\left(\frac{d}{d t} I_{i}^{2}\right) \frac{d t}{d R}+M_{i j} \frac{d}{d t}\left(I_{i} I_{j}\right) \frac{d t}{d R}\right]=0,
\end{aligned}
$$

and

$$
\frac{d R}{d t}=\frac{-\sum M_{i j} \frac{d}{d t}\left(I_{i} I_{j}\right)-\sum \frac{1}{2} L_{i i} \frac{d}{d t}\left(I_{i}^{2}\right)}{\sum\left[\frac{1}{2}\left(\frac{d}{d R} L_{i i}\right) I_{i}^{2}+\left(\frac{d}{d R} M_{i j}\right) I_{i} I_{j}\right]}
$$

In summary, the disruption process was simulated as a decay in lasma temperature in approximately $50 \mu \mathrm{s}$ with a uniform current aid temperature distribution. As the current then decayed, the major and minor radii became smaller. The rate at which this occurred was dependent on how fast the plasma-stored magnetic field energy could be absorbed by heating or could be supported by other adjacent circuits.

Because the worst-case condition is required for engineering designs of walls and limiters, the plasma temperature was assumed to drop to approximately $100 \mathrm{eV}$ and remain at this value during the current decay time. The added plasma thermal energy $\Sigma I_{p}^{2} \Omega t$, which is absorbed from its own magnetic field, produces the increased damage. It was assumed that this energy was conducted away from the plasma to the limiter and wall surfaces in contact with the plasma as fast as it was produced.

By the cime the plasma current goes to zero, all of its initial thermal energy has to be absorbed by the wall or limiter surfaces. The additional energy from the magnetic field, which is transferred to the plasma as thermal energy $\left(\sum l_{p}^{2} \Omega t\right)$, is also deposited on these same surfaces. The ablation and melting energy can only be reduced by reducing the plasma ohmic heating during the disruption. Thus, a fast current decay can result in the 
least melting of the surfaces. Engineering damage protection can best be achieved by having low-impedance structures and a high-resistance plasma during the current decay phase of disruption.

\section{Calculations}

The TFTR disruptions were first calculated for the as-built conditions with plasma currents of 1.0, 1.5, 2.0, and 2.5 MA and for initial plasma temperatures of 1 and $10 \mathrm{keV}$. Variations were then made in the following conditions:

1. plasma temperature (resistivity) during the current decay (Fig. 1);

2. vacuum vessel resistances - (a) increasing and decreasing the vessel resistance by a factor of 2 (Fig. 2), (b) increasing and decreasing the outside portion of the vessel wall (Fig. 3), (c) adding external passive coils to the outside of the vessel (which did not couple well enough to the plasma to have any effect); and

3. varying the thermal decay time $[50,100$, and $200 \mu s$ (Fig. 4)].

ORNL-DWG 84C-2436 FED

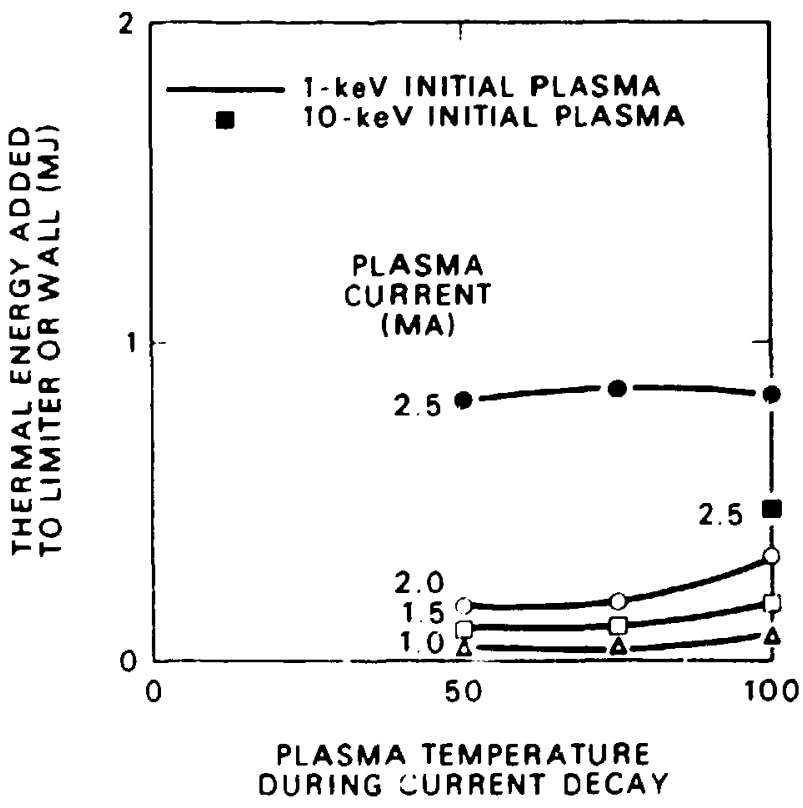

Fig. 1. Plasma temperature durbs curreat decay. 

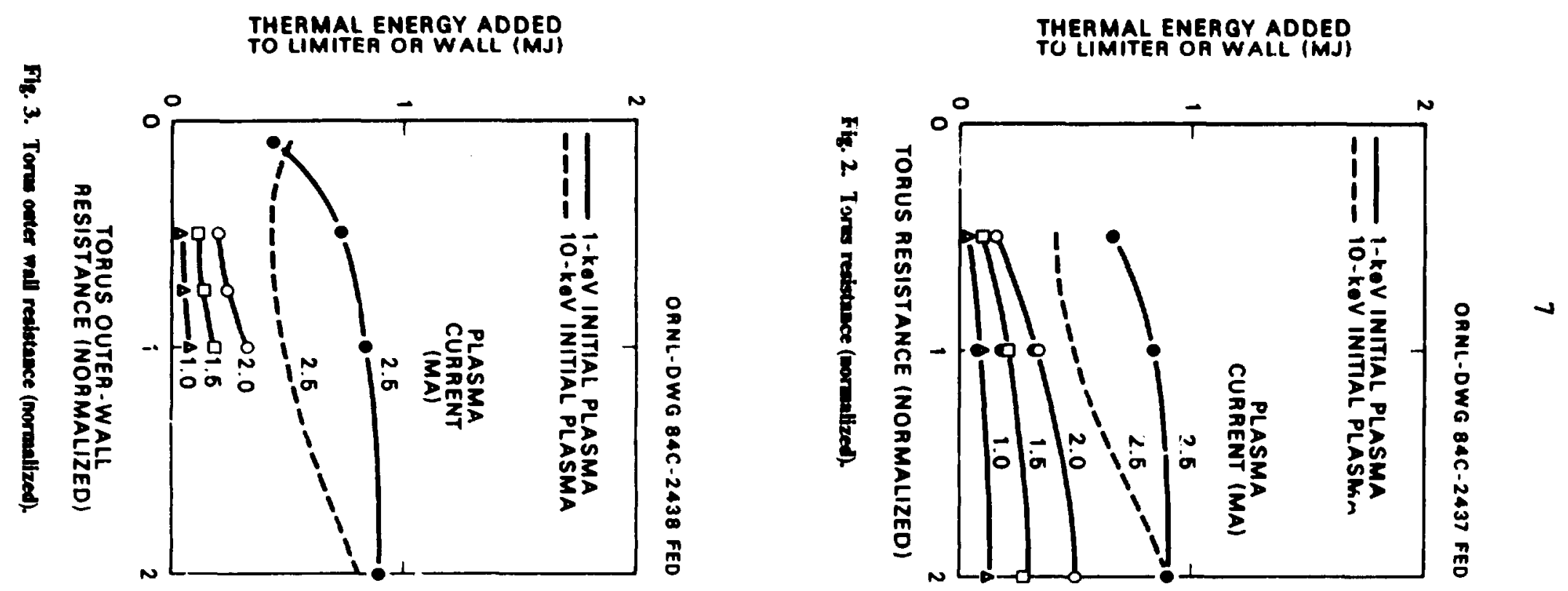
8

ORNL-DWG 84C-2439 FED

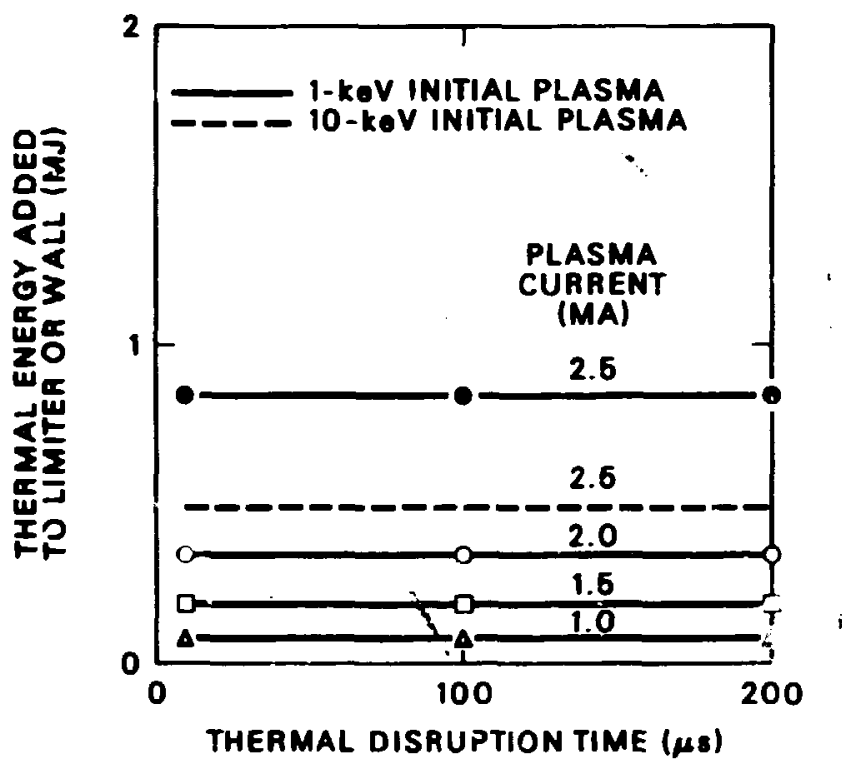

Fig. 4. Thermal dismption time (us).

Because it is the added magnetic energy that can be affected sy engineering designs, it was studied as the important factor. This delta energy, added to the first wall and limiter surfaces $\left(\sum I_{p}^{2} \Omega t\right)$, was plotted as the common parameter. The current decay times were also plotted (Fig. 5). The decay time varied roughly in proportion to the delta energy. The $10-\mathrm{keV}$ plasma produced a faster current decay time than a 1-keV plasma. This difference results from the larger change in the resistance during the first few microseconds of thermal decay. Curve sets on Figs. 6 and 7 show current decays as a fuliztion of tinse and for the $i-$ and 10-keV cases. Conditions for a 1.0-MA, 1-keV plasma art shown on the curve set of Fig. 8. (As exrected, the current decay is not linear, as now specified for designs.)

Table I provides calculated data on thermal energy at various plasma initial temperatures and the volume of material that would be lost for the case of all ablation or all melting. Table 2 provides data on the volume of material that could be vaporized or melted by the added magnetic energy. ( $A$ fast dump of energy results in a higher percentage of the total energy going to ablation.) This condition results in less loss of material, assuming mclt layers are pulled off the wall during disruption. Table 2 also provides comparative data on other possible first wall and limiter materials (quantifying material loss by abla. tion and melting) and shows the advantage of graphite ard the disadvantage of stainless steel, as compared to $\mathrm{SiC}$ and $\mathrm{BeO}$. 
THERMAI. ENERGY ADDED
TO LIMITER OR WALL (MJ)

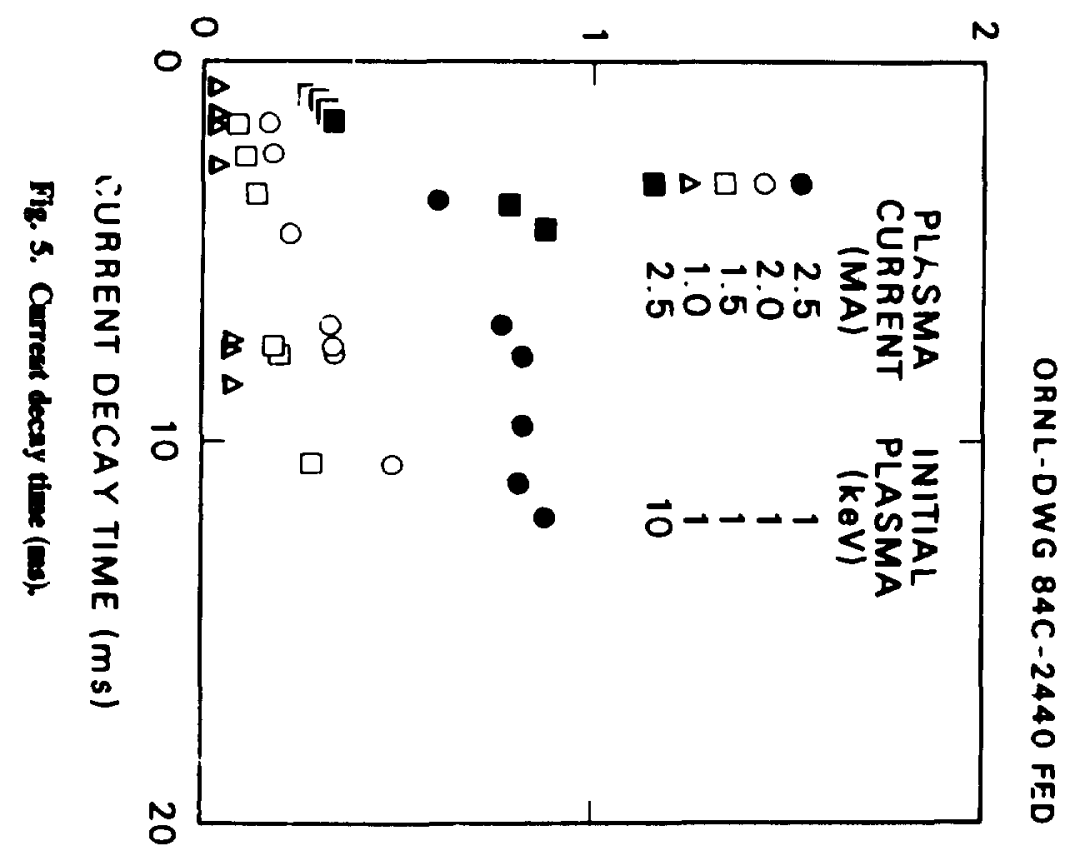


PLASMA CURPENT (MA) PLASMA RADIAL POSITION $(\mathrm{cm}$

PLASMA HEAT (MJ)

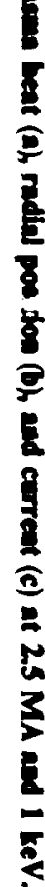

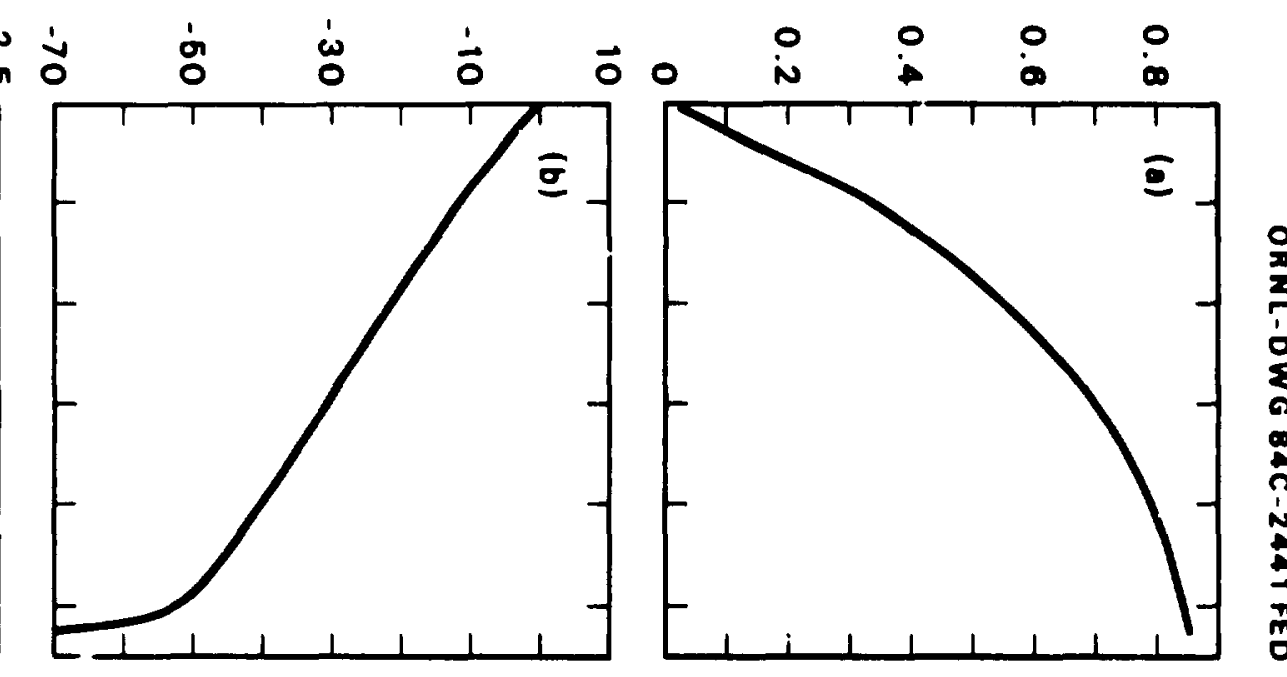



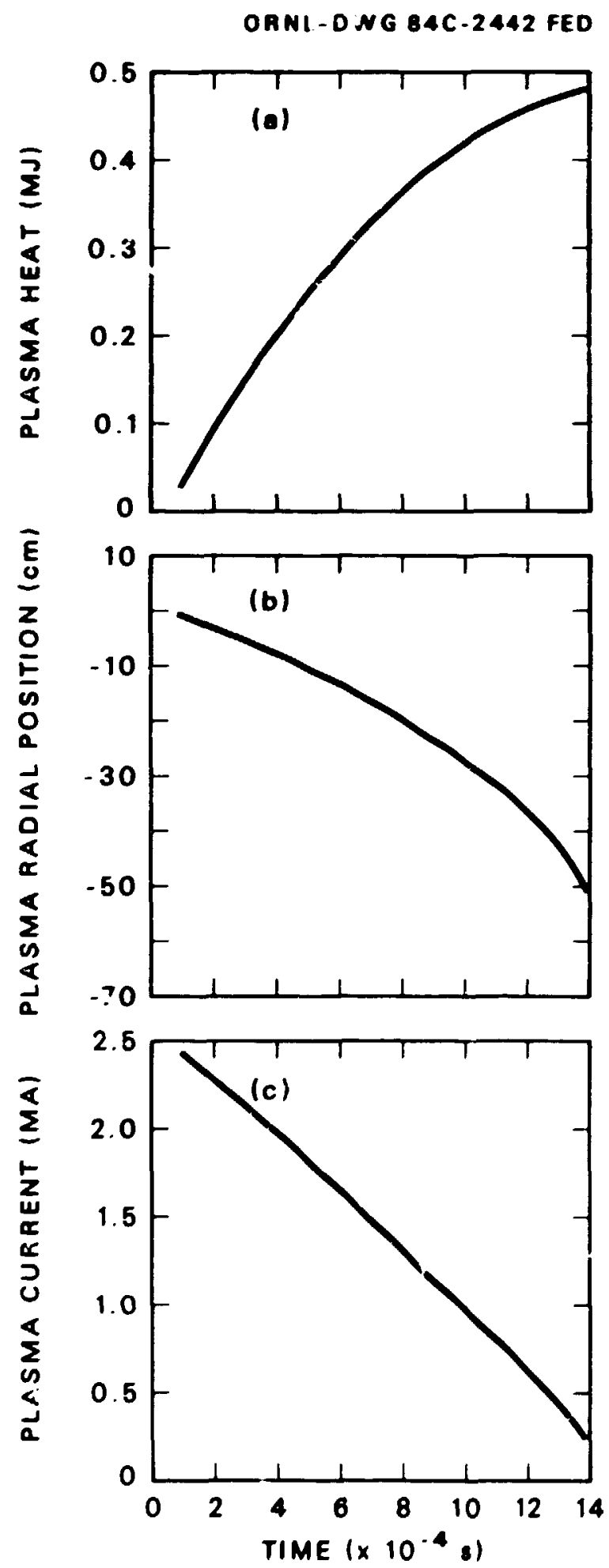

Fle. 7. Pleama beat (ah) radial poodtion (b) and carreat (c) at $2.5 \mathrm{MA}$ and $10 \mathrm{keV}$. 


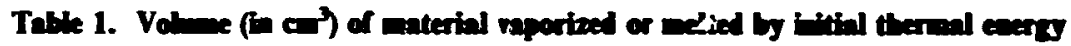

\begin{tabular}{|c|c|c|c|c|c|c|c|c|c|}
\hline \multirow{2}{*}{$\begin{array}{c}\text { Plasma } \\
\text { temperature } \\
\text { (keV) }\end{array}$} & \multirow{2}{*}{$\begin{array}{c}\text { Initial } \\
\text { thermal } \\
\text { energy } \\
\text { (kJ) }\end{array}$} & \multicolumn{2}{|c|}{ Graphite } & \multicolumn{2}{|c|}{$\mathrm{SiC}$} & \multicolumn{2}{|c|}{$\mathrm{BeO}$} & \multicolumn{2}{|c|}{ Stuinless } \\
\hline & & Vaporized & Melted & Japorized & Melted & Vaporizer & Melted & Vaporized & Melted \\
\hline 10 & 1800 & 17.2 & $a$ & 34.9 & 187.5 & 35.9 & 260.9 & 36.2 & 843.9 \\
\hline 5 & 900 & 8.6 & $a$ & 17.5 & 93.8 & 18.0 & 130.4 & 18.1 & 421.9 \\
\hline 2.5 & 450 & 4.3 & $a$ & 8.7 & 46.9 & 9.0 & 65.2 & 9.0 & 211.0 \\
\hline 1 & 160 & 1.7 & $a$ & 3.5 & 18.8 & 3.6 & 26.1 & 3.6 & 84.4 \\
\hline
\end{tabular}

Not applicab!e.

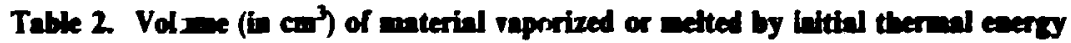

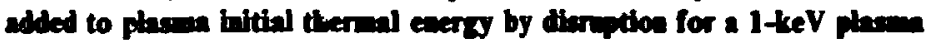

\begin{tabular}{|c|c|c|c|c|c|c|c|c|c|}
\hline \multirow{2}{*}{$\begin{array}{l}\text { Plasma } \\
\text { current } \\
\text { (MA) }\end{array}$} & \multirow{2}{*}{$\begin{array}{c}\text { Disruption } \\
\text { thermal energy } \\
\text { added to plasma, } \\
\sum J_{p}^{2} \Omega \mathrm{t} \\
\text { (kJ) }\end{array}$} & \multicolumn{2}{|c|}{ Graphite } & \multicolumn{2}{|c|}{$\mathrm{SiC}$} & \multicolumn{2}{|c|}{ BeO } & \multicolumn{2}{|c|}{ Stainless } \\
\hline & & Vaporized & Melted & Vaporized & Melted & Vapcrized & I Ielted & Vaporized & Melted \\
\hline 2.5 & 840 & 8.0 & $a$ & 16.3 & 87.5 & 16.8 & 121.7 & 16.9 & 393.8 \\
\hline 2.0 & 350 & 3.3 & $a$ & 6.8 & 36.5 & 7.0 & 50.7 & 7.0 & 164.1 \\
\hline 1.5 & 190 & 1.8 & $a$ & 3.7 & 19.8 & 3.8 & 27.5 & 3.8 & 89.1 \\
\hline 1.0 & 90 & 0.9 & $a$ & 1.8 & 9.4 & 1.8 & 13.0 & 1.8 & 42.2 \\
\hline
\end{tabular}

Not applicable. 
Calculations were also made on arc erosion, assuming ares would be produced across the bellows when the voltage across a single bellows reached a value of $25 \mathrm{~V}$. It was then assumc 1 that the current would continue flowing until the are voltage drupped to less than 20 V. For a 1.0-MA plasma, the total coulombs across each gap was 35 A.s. The current flow time was $2.5 \mathrm{~s}$; thus, the arc was assumed to have remained in a diffused state, with escentially no erosion. Extrapolating this calcclation to a 2.5-MA plasma, it is estimated that the are current would flow for $6.25 \mathrm{~s}$. It should remain in a diffused state and not produce erosion.

\section{CONCLUSIONS}

1. Arc erosion across the bellows during the current decay phase of disruption is not expected to be a major cause of damage, but additional calculations should be completed.

2. The only way disruption damage can be affected in a significant manner is to short out the bellows or to install passive conductors adjacent to the plasma. Shorting out the bellows would have to be done inside the vessel to be effective. This would probably require the addition of $\mathrm{rf}$ to assist startup. (Shorting some of the bellows increases the probability of arc damage on those not shorted.)

.. There is essentially no change in the disruption tinie with variations in the thermal time between 50 and $200 \mu \mathrm{s}$.

4. A higher initial thermal energy plasma results in a faster current decay time. The current decay time for a $2.5-\mathrm{MA}$ plasma at $10 \mathrm{keV}$ was calculated to be $1.5 \mathrm{~ms}$. This fast decay may overstress the insulation on the poloidal field (PF) coils. External passive circuits may be effective in relieving excessive voltage. This should be investigated further. 


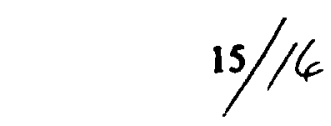

\section{ACKNOWLEDGMENTS}

The authors acknowledge the sonsultatiuns and discussions with Drs. John Schmidt (PPPL), Joseph Cecchi (PPPL), and Martin Peng (ORNL).

\section{REFERENCES}

1. J. Murray and G. Bronner, Disruption Model, PPPL 1909, Princeton Plasma Physics Laboratory, New Jersey, July 1982.

2. P. Barkin, J. Lafferry, T. Lee, and J. Talento, "High Current Vacuum Arc Stabilized by Axial Magnetic Fields," IEEE paper T7359-3, PAS-92-1973. 
ORNL/FEDC-84/2

Dist. Category UC-20 c,d

INTERNAL DISTRIBUTION

1. T. G. Brown

2. B. A. Carreras

3. J. L. Dunlap

4. G. M. Fuller

5. L. M. Hively

6. J. K. Johnson

7. S. S. Kalsi

8. R. R. Kindsfather

9. J. Kirchner

10. J. A. O'Toole

11-i5. K. E. Rothe

16. M. J. Saltmarsh

17. J. Sheffield
18. V. C. Srivastava

19. N. A. Uckan

20. T. Uckan

21. F. W. Wiffen

22-23. Laboratory Records Department

24. Laboratory Records, ORNL-RC

25. Document Reference Section

26. Central Research Library

27. Fusion Energy Division Library

28. Fusion Energy Division Publications Office

29. ORNL Patent Office

\section{EXTERNAL DISTRIBUTION}

30. M. A. Abdou, Associate Director, FPP/207, Argonne Natio:1al Laboratory, 9700 South Cass Avenue, Argonne, IL 60439

31. N. A. Amherd, Fusion Power Program, Advanced Systems Department, Electric Power Research Institute, P.O. Box 10412, Palo Aito, CA 94304

32. J. L. Anderson, CMB-3, Mail Stop 348, Los Alamos National Laboratory, P.O. Box 1633, Los Alamos, NM 87545

33. M. Anderson, Tennessee Valley Authority, 1300 Commerce Bank Building, Chattanooga, TN 37401

34. O. A. Anderson, Lawrence Berkeley Laboratory, University of California, Berkeley, CA 94720

35. D. J. Anthony, Advanced Power Program, Advanced Energy Programs Department, Building 2, Room 551, General Electric Company, Schenectady, NY 12345

36. C. C. Baker, FPP/208, Argonne National Laboratory, 9700 South Cass Avenue, Argonne, IL 60439

37. T. H. Batzer, L-5.36, Lawrence Livermore National Laboratory, P.O. Box 808, Livermore, CA 94550 
j\$. j. E. Baublitz, Office of Fusion Energy, Office of Energy Research. Mail Station G-256, Department of Erergy, Washington, DC 20545

39. W. Bauer, Physical Research Division, Sandia National Laboratories-Livermore, Livermore, CA 94550

40. j. F. Baur, GA Technologies, Inc., P.O. Box 81608, San Diego, CA 92138

41. D. S. Beard, Office of Fusion Energy, Office of Energy Research, Mail Stop G256, U.S. Department of Energy. Washington, DC 20545

42. R. J. Beeley, ETEC, Rockwell International, P.O. Box 1449, Canoga Park, CA 91304

43. D. C. Berkey, Vice President \& General Manager, Energy System and Technology Division, General Electric Company, P.O. Box 7600, Stamford. CT 06904

44. K. L. Black, Department E452, McDonnell Douglas Astronautics Company, P.O. Box 516, St. Louis, MO 63166

45. R. Botwin, C47-05, Grumman Aerospace Corporation, P.O. Box 31, Bethpage, NY 11714

46. W. B. Briggs, McDonnell Douglas Astronautics Company, P.O. Bex 516, St. Louis, MO 63166

47-51. G. Bronner, Princeton Plasma Physics Laboratory, P.O. Box 451, Princeton, NJ 08544

52. J. N. Brooks, FPP/207, Argonne National Laboratory, 9700 South Cass Avenue, Argonne, IL 60439

53. S. C. Burnett, GA Technologies, Inc., P.O. Box 81608, San Diego, CA 92138

54. J. D. Callen, Department of Nuclear Engineering, University of Wisconsin, Madison, WI 53706

55. V. S. Chan, GA Technologies, Inc., P.O. Box 81608, San Diego, CA 92138

56. R. G. Clemmer, Fusion Power Program, Argonne National Laboratory, 9700 South Cass Avenue, Argonne, IL 60439

57. D. R. Cohn, MIT Plasma Fusion Center, 167 Albany Street, Cambridge, MA 02139

58. W. S. Cuoper, Lawrence Berkeley Laboratory, University of California, Berkeiey, CA 94720

59. J. W. Coursen, C36-05, Grumman Aerospace Corporation, P.O. Box 31, Bethpage, NY 11714

60. R. W. Conn, School of Chemical, Nuclear, and Thermal Engineering, Boelter Hall, University of California, Los Angeles, CA 90024

61. J. G. Crocker, EG\&G Idaho, P.O. Box 1625, Idaho Falls, ID 83401

62. A. E. Dabiri, Energy Systems and Conse.vation Division, Science Applications, Inc., P.O. Box 2351, La Jolla, CA 92038

63. C. C. Damm, L-441, Lawrence Livermore National Laboratory, P.O. Box 808, Livermore, CA 94550 
64. R. C. Davidson, Massachusetts Institute of Technology, 77 Massachusetts Avenue, Cambridge, MA 02139

65. N. A. Davies, Office of Fusion Energy, Office of Energy Research, Mail Station G-256, U.S. Department of Energy, Washington, DC 20545

66. J. W. Davis, E457, Building 81/1/B7, McDonnell Douglas Astronautics Company, P.O. Box 516, St. Louis, MO 63166

67. M. J. Davis, Sandia National Labo:atories, P.O. Box 5800, Albuquerque, NM 87185

68. S. O. Dean, Director, Fusion Energy Development, Science Applications, Inc., 2 Professional Drive, Suite 249, Gaithersburg, MD 20760

69. J. F. Decker, Office of Fusion Energy, Department of Energy, Mail Stop G-256, Washington, DC 20545

70. D. DeFreece, E451, Building 81/1/B7, McDonnell Douglas Astronautics Company, P.O. Box 516, St. Louis, MO 63166

71. A. Deitz, Princeton Plasma Physics Laboratory, P.O. Box 451, Princeton, NJ 08544

72. D. A. Dingee, Program Manager, Fusion Technology, Pacific Northwest Laboratories, Battelle Boulevard, Richland, WA 99352

73. J. N. Doggett, L-441, Lawrence Livermore National Laboratory, P.O. Box 808, Livermore, CA 94550

74. H. Dreicer, Division Leader, CRT, Los Alamos National Laboratory, P.O. Box 1663, Los Alamos, NM 87545

75. D. Ehst, Argonne National Laboratory, 9700 South Cass Avenue, Argonne, IL 60439

76. G. A. Eliseev, I. V. Kurchatov Institute of Atomic Energy, P.O. Box 3402, 123182 Moscow, U.S.S.R.

77. W. R. Ellis, Office of Fusion Energy, Department of Energy, Mail Stop G-256, Washington, DC 20545

78. B. A. Engholm, GA Technologies, Inc., P.O. Box 81608, San Diego, CA 92138

79. H. P. Eubank. Princeton Plasma Physics Laboratory, P.O. Box 451, Princeton, NJ 08544

80. F. Farfaletti-Casali, Engineering Division, Joint Research Center, Ispra Establishment, 21020 Ispra (Varese), Italy

81. J. J. Ferrante, Manager, Building 36-241, Large Superconducting Program, Gener.l Electric Compa yy, I River Road, Schenectady, NY 12345

82. J. File, Princeton Plasma Physics Laboratory, P.O. Box 451, Princeton, NJ 08544

83. P. A. Finn, Fusion Program, Argonne National Laboratory, 9700 South Cass Avenue, Argonne, IL 60439

84. H. K. Forsen, Bechtel Group, Inc., Research \& Engineering, P.O. Box 3965, San Francisco, CA 94119

85. J. S. Foster, Jr., Building R4-2004, TRW Defense and Space Systems, 1 Space Park, Redondo Beach, CA 90278 
86. T. K. Fowler, Associate Director for MFE, L-436, Lawrence Livermore National Laboratory, P.O. Box 808, Livermore, CA 94550

87. J. W. French, EBASCO Services, Inc., Forrestal Campus, CN-59, Princeton University, Princeton, NJ 08544

88. H. P. Furth, Director, Princeton Plasma Physics Laboratory, P.O. Box 451, Princeton, NJ 08544

89. J. G. Gavin, Jr., President, A01-11, Grumman Aerospace Corporation, P.O. Box 31, Bethpage, NY 11714

90. G. Gibson, Westinghouse Electric Corporation, Fusion Power Systems Department, P.O. Box 10864, Pittsburgh, PA 15236

91. J. R. Gilleland, Manager, Fusion Project, GA Technologies, Inc., P.O. Box 81608, San Diego, CA 92138

92. V. A. Glukhikh, Scientific-Research Institute of Electro-Physical Apparatus, 188631 Leningrad, U.S.S.R.

93. M. Y. Gnhar, Argonne National Laboratory, 9700 South Cass Avenue, Argonne, IL 60439

94. W. D. Goins, Tennessee Valley Authority, 1300 Commerce Union Bank Building, Chattanooga, TN 37401

95. D. A. Goldberg, Lawrence Berkeley Laboratory, University of California, Berkeley, CA 94720

96. R. Goldston, Princeton Plasma Physics Laboratory, P.O. Box 451, Princeton, NJ 08544

97. M. B. Gottlieb, Princeton Plasma Physics Laboratory, P.O. Box 451, Princeton, NJ 08544

98. R. W. Gould, Department of Applied Physics, California Institute of Technology, Pasadena, CA 91109

99. M. W. Griffin, Department E236, McDonnell Douglas Astronautics Company, P.O. Box 516, St. Lo.is, MO 63166

100. C. R. Heat, Office of Fusion Energy, Department of Energy, Mail Stop G-256, Washington, DC 20545

101. W. Heinz, Institut für Technische Physik, Kernforschungszentrum Karlsruhe GmbH Postfach 3640, 7500 Karlsruhe 1, Federai Republic of Germany

102. C. D. Henning, Lawrence Livermore National Laboratory, P.O. Box 808, Livermore, CA 94550

103. G. K. Hess, Office of Fusion Energy, Department of Energy, Mail Stop ER-701, Washington, DC 20545

104. T. Hiraoka, JT-60 Project Office I, Japan Atomic Energy Research Institute, Tokai Research Establishment, Tokai, Ibaraki, japan

105. R. L. Hirsch, Manager, Synthetic Fuels Research, Exxon Research and Engineering Ccmpany, P.O. Box 4255, Baytown, TX 77520

106. J. J. Holmes, Westinghouse-Hanford Engineering Development Laboratory, P.O. Box 1970, Richlanr' 'VA 99352 
107. W. G. Homeyer, GA Technologies, Inc., P.O. Box 81608, San Diego, CA 92138

108. J. C. Hosea, Princeton Plasma Physics Laboratory, P.O. Box 451, Princeton, NJ 08544

109. D. Hwang, Princeton Plasma Physics Laboratory, P.O. Box 451, Princeton, NJ 08544

110. G. J. Inlikai, Department E23i, McDonnell Douglas Astronautics Company, P.O. Box 516, St. Louis, MO 63166

111. D. L. Jassby, Princeton Plasma Physics Laboratory, P.O. Box 451, Princeton, NJ 08544

112. J. B. Joyce, Princeton Plasma Physics Laboratory, P.O. Box 451, Princeton, NJ 08544

113. R. A. Krakowsi, CTR-12, Mail Stop 641, Los Alamos National Laboratory, P.O. Box 1663, Los Alamos, NM 87545

114. G. L. Kulcinski, University of Wisconsin. Department of Nuclear Engineering, Engineering Research Ruilding, Room 439, 1500 Jchnson Drive, Madison, WI 53706

115. D. L. Kummer, McDonnell Douglas Astronautics Comfany, P.O. Box 516, St. Louis, MO 63166

116. T. S. Latham, Mail Stop 44, United Technologies Research Center, Silver Lane, East Hartford, CT 06108

117. L. R. Ledman, Office of Fision Energy, Department of Energy, Mail Stop G256, Washington, DC 20545

118. L. M. Lidsky, MIT Plasma Fusion Center, 167 Albany Street, Cambridge, MA 02139

119. C. S. Liu, GA Technologies, Inc., P.O. Box 81608, San Diego, CA 92138

120. E. F. Lowell, General Manager, Energy Systems Programs Department, Building 2-455, General Electric Company, 1 River Road, Schenectady, NY 12345

121. D. J. McFarlin, Mail Ston 44, United Technologies Research Center, Silver Lane, East Hartford, CT 06108

122. R. McGrath, Fusion Power Program, Argonne National Laboratory, 9700 South Cass Avenue, Argonne, IL 60439

123. V. A. Maroni, CEN/205, Argonne National Laboratory, 9700 South Cass Avenue, Argonne, IL 60439

124. W. Marton, Office of Fusion Energy, Office of Energy Research, Mail Station G-256, U.S. Department of Energy, Washington, DC 20545

125. L. G. Masson. EG\&C, Idaho, Idahn National Engineering Laboratory, P.O. Box 1625, Idaho Fails, ID 83401

126. D. G. McAlees, Exxon Nuclear Company, Inc., 777 106th Avenue, NE, Bellevue, WA 98009

127. D. M. Meade, Princeton Plasma Physics Laboratory, P.O. Box 451, Princeton, NJ 08544 
128. A. T. Mense, Building 107, Post B2, McDonnell Douglas Astronautics Company, P.O. Box 516, St. Louis, MO 63166

129. L. Michaels, Princeton Plasma Physics Laboratory, P.O. Box 451, Princeton, NJ 08544

130. D. Mikkelsen, Princeton Plasma Physics Laboratory, P.O. Box 451, Princeton, NJ 08544

131. R. L' Miller, GA Technologies, Inc., P.O. Box 81508, San Diego, CA 92138

132. R. G. Mills, Princeton Plasma Physics Laboratory, P.O. Box 451, Princeton, NJ 08544

133. J. T. D. Mitchell, Culham Laboratory, Abingdon, Oxfordshire OX14 3DR, United Kingdom

134. R. W. Moir, Lawrence Livermore Laboratory, P.O. Box 808, Livermore, CA 94550

135. D. B. Montgomery, M. Г Plasma Fusion Center, 167 Albany Street, Cambridge, MA 02139

136. K. Moses, R-1/1078, TR W Defense and Space Systems, 1 Space Park, Redondo Beach, CA 90278

137. R. E. Muller, Aerojet Manufacturing Company, P.O. Box 4210, Fullerton, CA 92934

138. A. E. Munier, Grumman Aerospace Company, P.O. Box 31, Bethpage, NY 11714

139. P .. R. Murphy, Office of Fusion Enersy, Department of Energy, Mail Siation G-256, Washington, DC 20545

140-144. J. G. Murray, Princeton Plasma Physics Laboratory, P.O. Box 451, Princeton, NJ 08544

145. R. E. Nygren, FPP/207, Argonne National Laboratory, 9700 South Cass Avenue, Argonne, IL 60439

146. T. Ohkawa, GA Technologies, Inc., P.O. Box 81608, San Diego, CA 92138

147. M. Okabayashi, Princeton Plasma Pnysicj Laboratory, P.O. Box 451, Princeton, NJ 08544

148. D. Overskei, GA Technologies, Inc., P.O. Box 81608, San Diego, CA 92138

149. R. R. Parker, Francis Bitter National Magnet Laboratory, 170 Albary Street, Cambridge, MA 02139

150. B. Pease, Culham Laboratory, Abingdon, Oxfordshire OX14 3DB, United Kingdom

151. :.1. Pelovitz, Princeton Plasma Physics Laboratory, P.O. Box 4؟1, Princeton, N.\} 08544

152. F. W. Perkins, Princeton Plasma Physics Laboratory, P.O. Box 451, Princeton, IJJ 08544

153. M. Petravic, Princuton Plasma Physics Laboratory, P.O. Box 451, Princeton, NJ 08544

154. M. Porkolab, Massachusetts Institute of Technology, 77 Massachusetts Avenue, Cambridge, MA 02139 
155. D. E. Post, Princeton Plasma Physics Laboratory, P.O. Box 451, Princeton, NJ 08544

156. L. K. Price, Department of Energy, Oak Ridge Operations, P.O. Box E, Oak Ridge, TN 37830

157. R. E. Price, Office of Fusion Energy, Office of Energy Research, Mail Station G256, U.S. Department of Energy, Washington, DC 20545

158. D. H. Priester, Office of Fusion Energy, Office of Energy Research, Mail Station G-256, Department of Energy, Washington, DC 20545

159. F. A. Puhn, GA Technologies, Inc., P.O. Box 81608, San Diego, CA 92138

160. J. Purcell, GA Technologies, Inc., P.O. Box 81608, San Diego, CA 92138

161. R. V. Pyle, University of California, Lawrence Berkeley Laboratory, Berkeley, CA 94720

162. J. M. Rawls, GA Technologies, Inc., P.O. Box 81608, San Diego, CA 92138

16̇. P. J. Reardon. Princeton Plasma Physics Láboratory, P.O. Box 451, Princeton, NJ 08544

164. M. Roberts, Office of Fusion Energy, Department of Energy, Mail Stop G-256, Washington, DC 20545

165. J. D. Rogers, Los Alamos National Laboratory, P.O. Box 1663, Los Alamos, NM 87545

166. F. L. Robinson, Tennessee Valley Authority, 1300 Commerce Bank Building, Chattanooga, TN 37401

167. M. L. Rase:s, Monsanto Research Corporation, Mound Laboratory Facility, P.O. Box 32, Miamisburg, OH 45342

168. M. N. Rosenbluth, RLM 11.218, Institute for Fusion Studies, University of Texas, Austin, TX 78712

169. L. Ruby, Lawrence Berkeley Laboratory, University of California, Berkeley, CA 94720

17 P. H. Rutherford, Princeton Plasma Physics Laboratory, P.O. Box 451, Princeton, NJ 08544

171. D. D. Ryutov, Institute of Nuclear Physics, Siberian Branch of the Academy of Sciences of the U.S.S.R., Sovetskaya St. 5, 630090 Novosibirsk, U.S.S.R.

172. M. M. Sabado, EBASCO Services, Inc., A Site, Building 1-A, Forrestal Campus, Princeton, NJ 08.544

173. J. A. Schmidt, Princeton Plasma Physics Labnratory, P.O. Box 451, Princeton, NJ 08544

174. J. Schultz, MIT Plasma Fusion Center, 167 Albany Street, Cambridge, MA 02139

175. F. R. Scott, Electric Power Research institute, P.O. Box 10412, Palı Alto, CA 94304

176. G. Sheffield, Princeton Flasma Physics Laboratory, P.O. Box 451, Princeton, NJ 08544

177. C. E. Singer, Princeton Plasmi Physics Laboratory, P.O. Box 451, Princeton, NJ 08544 
178. T. J. M. Sluyters, Accelerator Department, Brookhaven National Laboratory, Upton, NY 11973

179. D. Smith, Materials Science Division, Argonne National Laboratory, 9700 South Cass Avenue, Argonne, IL 60439

180. G. E. Smith, Grumman Aerospace Corporation, P.O. Box 31, Bethpa

181. R. I. Smith, Board Chairman, Public Service Electric and Gas Company, 80 Park Place, Newark, NJ 07101

182. L. Soroka, Lawrence Berkeley Laboratory, University of California, Berkeley, CA 9i?20

183. L. Southworth, GA Technolugies, Inc., P.O. Box 81608, San Diego, CA 92138

184. I. Spighel, Lebedev Physical Institute, Leninsky Prospect 53, 117924 Moscow, U.S.S.R.

185. W. M. Stacey, Jr., Georgia Institute of Technology, School of Nuclear Engineering, Atlanta, GA 30332

186. D. Steiner, Rensselaer Polytechnic Institute, Nuclear Engineering Department, NES Building, Tibliets Avenue, Troy, NY 12181

187. E. Stern, Grumman Aerospace Corporation, CN-59, Forrestal Campus, Princeton, NJ 08544

188. L. D. Stewart, Princeton Plasma Physics Laboratory, P.O. Box 451, Princeton, NJ 08544

189. W. Stodiek, Princeton Plasma Physics Laboratory, P.O. Box 451, Princeton, NJ 08544

190. P. M. Stone, Office of Fusion Energy, Office of Energy Research, U.S. Department of Energy, Mail Station G-256, Washington, DC 20545

191. !. N. Sviatoslaviky, Room 33, Engineering Research Building, 1500 Johnson Drive, University of Wisconsin, Madison, WI 53706

192. T. Tamano, GA. Technologies, Inc., P.O. Box 81608, San Diego, CA 92138

193. R. E. Tatro, Manager, Energy Systems, M.Z. 16-1070, General Dynamics-Convair Division, P.O. Box 80847, San Diego, CA 92138

194. F. Tenney, Princeton Plasma Physics Laboratory, P.O. Box 451, Princeton, NJ 08544

195. F. Thomas, B-20-5, Grumman Aerospace Corporation, Bethpage, NY 11714

196. K. I. Thomassen, Lawrence Livermore National Laboratory, P.O. Box 808, Livermore, CA 94550

197. R. J. Thome, Francis Bitter National Magnet Laboratory, 170 Albany Street, Cambridge, MA 02139

198. S. L. Thomson, Bechtel Group, Inc., P.O. Box 3965, San Francisco, CA 94119

199. V. T. Tolok, Kharkov Physical-Technical Institute, Academical St. 1, 310108 Kharkov, U.S.S.R.

200. C. Trachsel, McDonnell Douglas Astronautics Company, P.O. Box 516, St. Louis, MO 63166 
201. J. R. Treglio, General Dynamics-Convair Division, P.O. Box 80847, San Diego, CA 92138

202. A. W. Trivelpiece, Office of Fusion Energy, Office of Energy Research, Mail Station G-256, Department of Energy, Washington, DC 20545

203. L. R. Turner, Fusion Power Program, Argonne National Laboratory, 9700 South Cass Avenue, Argoine, IL 60439

204. M. A. Ulrickson, Princeton Plasma Physics Laboratory, P.O. Box 451, Princeton, NJ 08544

205. E. H. Valeo, Princeton Plasma Physics Laboratory, P.O. Box 451, Princeton, NJ 08544

206. T. C. Varljen, Westinghouse Electric Corporation, P.O. Box 10864, Pittsburgh, PA 15236

207. R. Varma, Physical Research Laboratory, Navangpura, Ahmedabad, India

208. H. F. Vogel, Los Alamos Nat:onal Laboratory, P.O. Box 1663, Los Alamos, NM 87545

209. A. Wait, Building 36-421, General Electric Company, 1 River Road, Schenectady, NY 12345

210. K. E. Wakefield, Princeton Plasma Physics Laboratory, P.O. Box 451, Princeton, NJ 08544

211. D. Weldon, Los Alımos National Labnratory, P.O. Box 1663, Los Alamos, NM 87545

212. J. C. Wesley, GA Tecinologies Inc., P.O. Box 81608, San Diego, CA 92138

213. S. Whitley, Tennessee Valley Authority, 1300 Commerce Bank Building, Chattanooga, TN 37401

214. W. R. Wilkes, Monsanto Research Corporation, Mound Laboratory Facility, P.O. Box 32, Miamisburg, OH 45342

215. J. E. Wilkins, EG\&G Idaho, Idaho National Engi eering Laboratory, P.O. Box 1625, Idaho Falls, ID 83401

216. H. Willenberg, Mathematical Sciences Northwest, Inc., P.O. Box 1887, Beilevue, WA 98009

217. J. E. C. Williams, Francis Bitter National Magnet Laboratory, 170 Albany Street, Cambridge, MA 02139

218. P. Willis, Building 23, Room 298, General Electric Company, 1 River Road, Schenectady, NY 12345

219: - T. F. Yang, MIT Plasma Fusion Center, 167 Albany Street, Cambridge, MA 02139

220. H. H. Yoshikawa, W/A-62, Hanford Engineering Development Laboratory, P.O. Box 1970, Richland, WA 99352

221. K. M. Young, Princeton Piasma Phy,ics Laboratory, P.O. Box 451, Princeton, NJ 08544

222. N. E. Young, EBASCO Services, Inc., Princeton Plasma Physics Laboratory, P.O. Box 451, Princeton, N.I 08544 
223. K. M. Zwilsky, National Materials Advisory Board, National Academy of Sciences, 2101 Constitution Avenue NW, Washington, DC 20418

224. Bibliothek, Max-Planck Institut fur Plasmaphysik, D-8046 Garching bei Munchen, Federal Republic of Germany

225. Bibliothek, institut fur Plasmaphysik, KFA, Postfach 1913, D-5170 Julich, Federal Republic of Germany

226. Bibliotheque, Service du Confinement des Plasmas, CEA, B.P. No. 6, 92 Fontenay-aux-Roses (Seine), France

227. Documentation S.I.G.N., Depertment de la Physique du Plasma et de la Fusion Controlee, Association EURATOM-CEA, Centre d'Etudes Nucleaires, B.P. 85, Centre du Tri, 38041 Grenoble, Cedex, France

228. Library, Centre de Recherches en Physique des Plasmas, 21 Avenue des Bains, 1007 Lausanne, Switzerland

229. Library, Culham i aboratory, UKAEA, Abingdon, Oxfordshire, OX14 3DB, England

230. Library, FOM Institut :orr Plasma-Fysica, Rijnhuizen, Jutphas, Netherlands

231. Library, Institute of Physias, Academia Sinica, Beijing, Peoples Republic of China

232. Library, Institute for Plasma Physics, Nagoya University, Nagoya 464, Japan

233. Library, International Centre for Theoretical Physics, Trieste, Italy

234. Library, JET Joint Undertaking, Abingdon, Oxfordshire, OX14, DB, England

235. Library, Laboratoria Gas Ionizzati, Frascati, Italy

236. Plasma Research Laboratory, Australian National Laboratory, P.O. Box 4, Canberra, ACT 2000, Australia

237. Thermonuclear Library, Japan Atomic Energy Research Institute, Tokai, Naka, Ibaraki, Japan

238. Library, Plasma Physics Laboratory, Kyoto University, Gokasho Uji, Kyoto, Japan

239. Office of the Assistant Manager for Energy Research and Development, Department of Energy, Oak Ridge Operations, Oak Ridge, TN 37830

240-443. Given distribution as shown in TID-4500, Magnetic Fusion Energy (Distribution Category UC-20 c,d: Reactor Materials and Fusion Systems) 